\title{
Transformation of University Libraries During the Digital Era
}

\author{
Ruslan A. Baryshev, Irina A. Tsvetochkina, \\ Olga I. Babina, Elena N. Kasyanchuk \\ and Margarita M. Manushkina* \\ Siberian Federal University \\ Krasnoyarsk, Russian Federation
}

Received 18.04.2020, received in revised form 04.06.2020, accepted 01.07.2020

\begin{abstract}
The paper considers the transition period of society development, based on the use of digital information and communication technologies. Now the digital economy covers all the spheres of society, so the question of its study is relevant. The transition to a new digital economy model contributes to improving the life quality of the population. In higher education institutions educational paths are changing, a rapid transition from physical to virtual reality is observed. However, the educational environment lags far behind the pace of industrial production based on modern technologies. In such situation, approaches to modernizing the training system need to be developed. This case university strategies, aimed at creating a full environment for the development of education and science, information and knowledge from the intellectual global environment, are being developed. In the context of the transition to digital technologies in education, the library, as one of the main structural divisions of the university, should also become digital.

The paper reveals the different viewpoints of the library community that show the strategy and direction of library development for the digital environment. Libraries are now actively developing information and communications technology providing services to their users, while maintaining traditional forms and methods of working with readers. This symbiosis meets the needs of different groups of readers and users.

On the basis of theoretical research of formation processes and development of electronic library, problems of transition period are considered, strategy of digital library development is identified, technologies of creation and introduction of information resources into university educational environment are determined.

The purpose of the research was to study the activity of using information resources in the educational process and research activities, in order to improve the quality of service to library users. It will identify the attitudes of students towards information resources and library services.
\end{abstract}

\footnotetext{
(C) Siberian Federal University. All rights reserved

* Corresponding authorE-mail address: babina62@yandex.ru, r_baryshev@bk.ru, tsia12@mail.ru, kasyanchuk@inbox.ru,margma@yandex.ru

ORCID: 0000-0002-4383-2830 (Baryshev); 0000-0002-8568-6042 (Tsvetochkina); 0000-0001-6138-8983 (Babina); 0000-0002-9909-3205 (Kasyanchuk); 0000-0002-2369-1882 (Manushkina)
} 
The relevance and importance of the transition to the digital library is noted, the impact of this process on the development of all library activities is analysed, while maintaining the continuity of its main functional purpose. In addition, the emergence of new social and technological tasks is indicated, the specifics of working with digital users are distinguished. The library works with both virtual users and real readers. Book loan and electronic resources to users are analyzed. The library's activities are covered in educational and leisure activities with university students and teachers.

In the article, the recommendations presented will improve the efficiency of the library.

Keywords: fourth industrial revolution, digitalization, digital economy, virtual environment, libraries, information resources, library services.

Research area: history, culturology.

Citation: Baryshev, R.A., Tsvetochkina, I.A., Babina, O.I., Kasyanchuk, E.N, Manushkina, M.M. (2020). Transformation of university libraries during the digital era. J. Sib. Fed. Univ. Humanit. Soc. Sci., 13(7), 1073-1089. DOI: 10.17516/1997-1370-0627.

\section{Introduction}

Now fundamental changes are taking place in all spheres of society 's life. Such a period is commonly referred to as transformation. Modern society is developing in the context of the total spread of the Internet and the growth of digital technologies that transform the economic, social, cultural and humanitarian environment of our habitat. It changes our lives and the lives of future generations. Transformation is taking place at the level of governments, state institutions, health care, education, etc.

Dr. Klaus Schwab (2016) believes that the fourth industrial revolution is coming, based on the integration of 'cyberphysical systems' into production processes. These systems have the ability to self-adjust and self-learn. Schwab also points to "the mixing of the technologies of the physical, digital and biological worlds that is going to create new opportunities and affect political, social and economic systems". The projected fourth industrial revolution means the emergence of a fully digital industry based on the mutual intersection of industrial and information technologies. The field of application of cyberphysical systems will be extended to all human activities, including economic systems, all types of systems that will support us in our daily lives from medicine to smart houses and cities. The creation of full-fledged cyberphys- ical systems (Internet of People, Internet of Things and Internet of Services) in the future will lead to approximately the same changes in interaction with the physical world, which led to the World Wide Web (Chernyj, 2018).

With the development of the fourth industrial revolution, terms and phrases such as the digital environment, digitalization and the digital economy are being introduced into our lives. As a rule, the term digital economy refers to a system of economic relations based on the use of digital information and communication technologies. Schreiberg (2018) defined the digital economy as an economy in which all processes are organized online, that develops through the Internet and actively uses information and communication processes and technologies.

The transition to the digital economy and digital society, as the most significant development priorities of any State, updates and increases the importance of the process of digitalization of vocational education. University libraries, as members of the educational community, are called upon to participate in the creation of key conditions in the training system. Libraries should participate in the implementation of educational and research activities of the university, contribute to the formation of an independently and creatively thinking, educated personality. 
The processes taking place in modern society influence libraries and force them to change not only the whole system of library's work and resources, but also for the first time raise the question of the very foundations of existence of traditional libraries and their functions. Chunmeng et al. (2019) suppose that the development of technology has made traditional libraries face unprecedented challenges and impacts. Throughout its history, the library has developed from a repository of knowledge for the few chosen to the most popular and universal source of information. However, now there is a marked lag in the development of libraries from the level of modern society. Therefore, in its traditional understanding in the life of modern society, the library plays an increasingly smaller role. That's why the library must determine its place and role in the digital environment.

In the modern world, the library should constantly develop, introduce information technologies: create electronic catalogs, digitize books, launch Internet analogues of the library. The modern library destroys its physical boundaries, moving from real environment to the virtual one. On the one hand, it offers access to information resources owned by other information aggregators, on the other - itself becomes interactive, digitizing its funds and cooperating with other libraries through the Internet (Rosa, 2019; Lenka et al., 2017). The main role of the library is to structure, organize information resources and meet user's needs.

The growing dynamics of technological, economic, social and cultural change poses new tasks for libraries:

- Optimization of library's inner processes based on digital technologies;

- Giving access to the main fund of printed books to everyone who needs it;

- Modernization of the library environment;

- Development and improvement of library services;

- Meeting users' information needs.

The main function of the digital era libraries is to help the community it serves to solve problems related to intellectual activity and adaptation to constant external innovation. The library is transformed into a multi-functional institution, simultaneously performing several tasks of equal importance, which are components of its main activity (Stepanov, 2017). It should be noted that the latest amendments to the Law "About Library Business" (2019) declare the task of forming a "unified Russian electronic knowledge space".

The purpose of this research is to determine the role and place of the university library in the conditions of constant changes according to the requirements presented to universities in the training of competent specialists.

\section{Literature review}

\subsection{Legislative base for the development of the digital economy in Russia}

The digital transformation of the Russian economy is becoming one of the main strategic directions of its development. The main peculiarities of the development of Russian society and economy in the context of the fourth industrial revolution were reflected in the National Technological Initiative (2016). A system of road maps, which are implemented in the form of projects, has been identified as the main tool for this initiative.

During 2017-2019, the rate of digitalization has extremely increased in Russia. It was facilitated by the Letter of the President of the Russian Federation V.V. Putin to the Federal Assembly of the Russian Federation on the $1^{\text {st }}$ of December in 2016. He spoke about the need to develop the economy of the new technological generation, the so-called digital economy (2016). The development of the digital economy is a strategically important issue for Russia as a whole, determining its competitiveness on the world scene. The changing regulatory framework in Russia is aimed at more rational management of educational technologies. In accordance with Presidential Decree No. 203 of on the 9th of May in 2017 "About Strategy for the Development of the Information Society in the Russian Federation for 2017-2030", one of the most important tasks of the development and application of information and communication technologies for the social sphere is the creation of various technological platforms for distance learning 
in order to increase the availability of quality educational services (2017).

Speaking on the $2^{\text {nd }}$ of June in 2017 at the plenary session of the St. Petersburg International Economic Forum, Vladimir Putin specified that the digital economy will let create qualitatively new models of business, trade, logistics, production, will change the format of education, health care, public administration, communications between people, and, therefore, would set a new paradigm for the development of the whole society (2017).

Order No. 1632-r on the $28^{\text {th }}$ of July in 2017 the Program "Digital Economy of the Russian Federation" was approved, which defines the conditions for the development of the digital economy in Russia, where digital data is a key factor of production in all spheres of social and economic activity (2017). At the St. Petersburg Economic Forum in May 2018, much attention was paid to the creation and development of knowledge environment, strengthening the digitalization of education.

The National Programme "Digital Economy of the Russian Federation" (2018) is closely linked to the national projects "Education" (2018), "Science" (2018), "Culture" (2018) and such federal projects as "Regulation of the Digital Environment" (2018), "Personnel for the Digital Economy" (2018), "Digital Technologies" (2018), "Digital Government" (2018), etc.

The adopted normative and legal acts have started the development of the main directions and activities of digital activity in our country. The government has determined that digitalization of the economy will help Russia to solve problems of competitiveness and national security of the country. Thus, all normative and legal acts characterize the state of Russia in the relevant period and outline prospects and directions of development.

\subsection{University education in the era of digitalization}

The society digitalization development requires people to be flexible and mobile, be able to adapt to changes. In these circumstances, the need to change the system of training of personnel of the highest qualification becomes important for the increasingly changing tech- nological order. Aleksankov (2017) notes that for a long time most the foreign universities passed in industrialized countries a stage of practical introduction of such models as Lifelong Learning, Learning by Doing, model of variable training, etc.

However, we already know that the existing educational system can't keep up with changing needs of rapidly developing industrial production based on new technologies. This situation has led to a conceptual reflection on approaches to modernize the training systems.

The main features, generated by the digital era in this sphere, are (Kondakov, 2017):

1. Education becoming the largest intangible asset of any state. Therefore, its formation and capitalization should be as manageable as possible.

2. The development of digital technologies and telecommunications of the network society changes the ways of creating, transferring and fixing knowledge, the process of personal development of the person, his/her self-identification. Therefore, education that meets the diverse needs of a networked society must also become networked.

3. Digital technologies becoming transnational and transcultural, publicly available and relatively cheap, making any knowledge publicly available.

4. A significant part of innovation in education is already being implemented today through educational and technological startups. As a result, outside the formal education system, there is a rapidly growing market for educational services that can lead to new educational standards that meet the emerging and rapidly changing demands and needs of consumers.

5. The dynamics of economic development in conditions of uncertainty, rapid change of technologies create a demand for new competencies and forms of training, including skills and competencies of the twenty-first century; "fast" education under a narrow range of tasks; "long life learning" education ("education on demand", continuous obtaining new knowledge and competences is formal, informal) in the conditions of rapid technological, economic, social and cultural changes. 
Thus, the main challenge of the educational system is to change the life cycle of technologies and goods based on the jobs that are required to service these technologies and goods. Today, the life cycle of technologies is becoming comparable to that of training, and there is an increasing threat of disappearance of jobs training for which has begun. If we follow the principle of compliance of the production and educational paradigm, then naturally there is a need for systemic changes in the educational environment. According to Aleksankov (2017), such changes are already being implemented in leading foreign universities and can be classified as following: digitalization of education, personalization of education, design approach, creation of creative environment, creation of inter-university platforms, integration of formal and informal education.

\subsection{Problems of library development in the period of digitalization}

Professional journals have been discussing possible library reforms for many years. The issue of library modernization still remains open. Nowadays, the process of reform causes the emergence of library activities that are not directly related to the traditional mission of a library: the process, designated by Professor Sokolov (2009) as "debunking", is taking place. The library's original function (collect - store - grant access to documents) is changing. As a result, the role of the library as a social institution changes dramatically (Stepanov, 2017).

The non-informative reasons to visit library are created by foreign and domestic libraries make the task of understanding the library mission relevant. Tikhomirova (2012) spoke a lot about this issue. She noted that the traditional mission of the library, "aimed at socially significant big business, is replaced by small, household affairs". Analyzing the current situation, Babich (2017) estimates the development of social and cultural activities of public libraries as a form of "struggle for survival". The author concludes that reading is replaced by leisure activities and social services that are not characteristic of libraries in their history.
Foreign libraries are also interested in such issues as 'Why do we need library when everything is on the Internet?' or 'Do universities still need to invest in the libraries?' This study argues that libraries are important but, like other organizations, they need an ongoing transformation to remain relevant. In this regard, digital technologies could play a critical role to support such transformation (Limwichitr, 2019).

Russian libraries, in order to remain relevant, have to use extreme measures (Kovaleva, 2013). Library staff offer users non-standard services, create conditions for informal communication of readers. Thus, the author presents the library as a public platform for comfortable communication. Librarians implement a modern international understanding of the library's role as a "public place". Ultimately, this allows the library to unlock the underutilized potential of a significant institution in the formation of civil society (Sokolskaya, Russak, 2015).

From Basov's point of view (2008), "libraries can claim to be the main social institution operating in the sphere of free time, on civic socialization of the population". The same view is held by Sokolskaya et al. (2015). They believe that libraries should realize the most important functions of the social institution educational, socializing within the framework of leisure activities. Libraries should be a platform for bringing people together for different interests.

The current problems of the library sphere related to the definition of the mission of libraries, their role and place in modern society are presented by Mazuritsky et al. (2019). It is accentuated that the library sphere needs to be modernized. The authors note the lack of a clearly defined public policy in the field of library affairs, which makes it difficult to form library's new unified concept. The main thing about libraries responses to time challenges is their theoretical justification, practical testing, mobility and timeliness.

Rassadina (2018) defines the change of functions of the library in conditions of informatization of society. The functionality of the modern library has long gone beyond the usual 
limits, first of all it is due to the needs of the society, used to receive as much service as they can in one point. The search for new forms of work, the rejection of established stereotypes, the use of modern technologies - this is what is necessary in libraries today, in author's opinion.

Research scientists Gendina, Ryabtseva (Gendina, Ryabtseva, 2018), on the basis of processes analysis taking place, reveal four essential entities of the library as a social institution: the library as a phenomenon of culture, the library as a centre of socially and culturally significant information, the library as a foundation for the development of science and new ideas, the library as a stabilizing social factor.

In library science, the problem of classifying library functions as a social institution is debatable. Its social functions often include information, educational, hedonistic, ideological, cultural and educational, compensatory, research and production, educational, pedagogical, cognitive, educational, recreational, educational, memorial, social and cultural, etc. In conditions of global crises, including financial crises, the library should implement its mission, defend the performance of native essential functions even if the current state cultural policy and interests of society do not match (Gendina, Ryabtseva, 2018; Kuznetsova, 2019).

In digital society, citizens have specific needs. Stepanov (2018) determines that the functions of the library as a public institution should be rethought and defined on the basis of these basic needs, as the purpose of the library of the new type is to meet the cognitive interests of citizens. Under fundamentally changed conditions, the library is designed to provide an adequate set of needs-oriented services to their interests. From the institution that collects, stores and provides the public use of the documentary array, the library should become an open innovation and education platform. This platform should support all forms of knowledge and competences for users to adapt to constantly changing living conditions.

In general, taking into account the latest trends presented in professional printing, conferences and exhibitions, the following modern trends in the development of library affairs in the digital environment can be distinguished: inclusivity, artificial intelligence, green libraries, open access and scientific research, development of "live content", data organization and information search, taxonomy (Schreiberg, 2018).

The library of the future is certainly becoming not only an integral part of the domestic and world information infrastructure, but also one of the main platforms for the formation of the knowledge space. It is libraries - those social, scientific, information and educational institutions, which all their existence support confidence that knowledge will be created in libraries and serve people, the country, society.

\subsection{University library in the era of digitalization}

Modern concepts of education imply the integration of digital components into the educational process and lead to the creation of a new type of educational institution - a 'digital university'. Accordingly, the library, as one of the main structural subdivisions of the university, should become 'digital'. Digital library makes the accessibility of the information more productive and effective (Raza, 2019; Lippincott, 2015). Digital library is a digital form of library collections and services which includes digitized files of information, cataloged, indexed, and with professional assistance available to help users (Shen, 2019). In a competitive environment, the library can survive only by gaining its own unique place in the digital communications system, providing vital services that no other organization can provide in equal volume and with the same quality.

Modern trends in the development of university libraries are actively discussed in domestic (Russian) periodicals. The library is an integral part of any university. Today it should be a strategic partner of the university, be in continuous interaction with various structures within the university. The main role of the library is to form various kinds of information resources, to provide information to students, teachers, employees of the university (Shamatonova, 2017). 
As a structural division of the university, the library is restructuring its activities according to the goals and objectives of the university. Vtyurina (2019) emphasizes that the main tasks of the university library are to ensure physical and electronic access to educational, scientific and information resources, as well as the organization of modern information and library space.

In Kudryashova's monograph (2004) the author specifies that throughout the years of existence the main social functions of the university library remain unchanged - satisfaction of educational requests, preservation and provision of information. Nevertheless, the emphasis on the social role of university libraries is changing.

The modern model of the university library implies its purposeful and effective development on the basis of a carefully designed, structured and planned system of measures, which include the priority of stages, the sequence of their implementation, the availability of resources. University libraries' mission is to be the center of integrated information support of training and research processes. In modern conditions, the mission of the university library can be formulated as following: select, complete, systematize information and provide access to it to university staff and students (Otstavnova et al., 2018).

Modern reader has many demands to the library. He/she wants to receive documents (articles, copies of the source, monographs, textbook) without leaving his/her house (Schreiberg, 2018). The main tasks of libraries today are to improve public access to information and knowledge; to increase the availability of information and communication services; to develop and improve dialogue with user; to improve the level of information awareness of users who should have the necessary competencies (Schreiberg, 2019).

Vahrushev (2018) considers the purpose of the university library to be related to the creation and maintenance of the university's scientific library open archive functioning. He notes that the creation of an open archive is in demand by the scientific community, as all materials stored in it are free of charge. An open archive, formed on a disciplinary or interdisciplinary basis, can become the basis for the creation of an informal association (collaboration, consortium, etc.) around a scientific school or research center (faculty, institute, university, scientific organization).

The conceptual model of the digital era library of a new type, according to Kuznetsov (2019), involves its three-component functional structure: 1) participation in the organization and management of information and knowledge; 2) preserving and ensuring access to cultural and historical documentary heritage, broadcasting cultural samples and humanistic social moral and ethical values; 3 ) development of social relations and relations with various structures of modern society as an active subject of the system of social communications, including intercultural ones.

Gurdish (2018) wrote that the role of academic libraries in the digital transformation of the universities becomes central. Only those universities that stay relevant and leverage the power of digital and put in place focused digital transformation will survive in the digital era.

Thus, the modern library of the university today should be considered not only as a space for readers to store and receive the necessary information, but also as an educational system for the formation of innovative thinking among readers.

\section{Materials and methods}

\subsection{Research phases}

All the work carried out under this study can be divided into three main phases.

At the first stage, a detailed analysis of scientific sources was carried out, on the basis of which it was possible to identify existing approaches to the development of university libraries in the conditions of digitalization.

In the second phase, the study examined the usage activity of information resources in the educational process and research activities, with an aim to improve the quality of service to library users. The study identified students' priorities in using library information resources and services.

At the third stage, the analysis of the activity of the Scientific Library of Siberian Fed- 
eral University (hereinafter the SFU Scientific Library) was carried out in three main areas of development - formation of information resources, provision of their library users, interaction with library users. The analysis showed that the library is ready to move to a digital environment. The results of the study will improve the efficiency of the library.

\subsection{Experimental base of a research}

The scientific library of Siberian Federal University is the experimental base of this study.

\subsection{Analysis of information needs of library users}

Improving the quality of services and working conditions of readers is one of the priorities of the SFU Scientific Library. The questionnaire is conducted regularly in order to attract students to the library and study their interests. The questionnaire method ensures the anonymity of an interviewed, what allows to gather reliable information. This questionnaire was conducted in the form of a written response to questionnaire questions and an online questionnaire. The purpose of the study is to identify the needs of library users to determine further service improvements. 520 SFU students participated in the study. The questionnaire contained nine questions.

The first question 'How often do you use the library services?' determined that more than a third part of respondents $(38.4 \%)$ visit the library once or twice a week, $23.1 \%$ visit the library more often than twice a week, the same number of users use the library services once or three times a month, the rest of respondents $(15.4 \%)$ indicated other options - "as necessary", "almost never", "when the laptop breaks down", etc. Such activity of users can be explained by the availability of Internet resources. Students come to the library if they cannot find the necessary information on the Internet on their own or when the use of certain library literature is an important condition for successful study of the course or when their teacher's demand.

To the second question, 'Do you know that library services can be used remotely?', 40\% of respondents said that they know about them and sometimes use them, $26.2 \%$ of respondents know but do not use services; $21.9 \%$ of respondents noted that they do not know about services and only $11.9 \%$ of respondents regularly use the library remotely. It can be noted that online services are demanded by users. $30.6 \%$ of users have problems while looking for information, $55.8 \%$ of users sometimes have difficulties with finding information, $21.9 \%$ of respondents said that they always find the necessary information. The findings indicate that it is necessary to implement training activities for students more actively.

The fourth question was asked to form the information literacy program of users: 'What forms of training to find information and work with information resources in the library are the most attractive for you?' (see Fig. 1). Most of respondents chose online consultations, re-

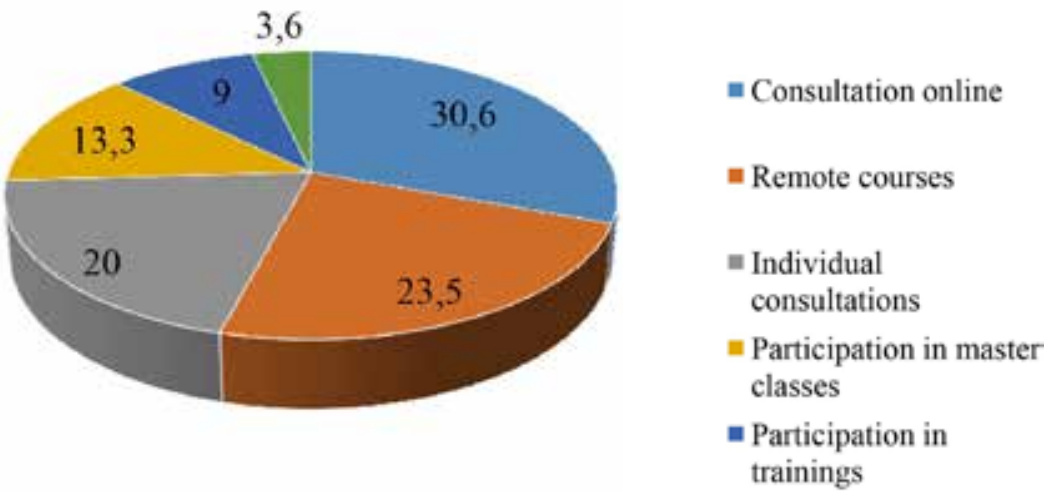

Fig. 1. Information Resource Training Forms 
mote courses were chosen by $23.5 \%$. Individual consultations were noted by $20 \%$ of respondents; $13.3 \%$ of respondents expressed their desire to take part in master classes; $9 \%$ of respondents said they would choose trainings, and only $3.6 \%$ of students would like the curriculum to include disciplines "Basics of information culture" and "Information resources". Accordingly, online consultations and distance courses need to be developed.

To the question 'What information resources are you more comfortable to use?' slightly more respondents chose electronic resources over printed editions (see Fig. 2). Such data indicate that among users both electronic resources and printed publications are popular.

Personal Cabinet, the reader's personal account in the SFU Library has become a service since 2013. It is a personalized virtual workspace of a student, teacher or university employee in closed access. Services are provided according to user's status and permissions. The library reader enjoys the full range of online services provided. The services of the Personal Cabinet are used by $63.3 \%$ of respondents, respectively, $36.7 \%$ of users do not use it. The advantages and ease of obtaining the necessary information through the services of the Personal Cabinet should be advertised.

The next question was about the use of electronic resources acquired by a library (see Fig. 3). The SFU Library provides access to 15 Russian and 37 foreign databases. Analysis of foreign electronic resources usage showed that only $8 \%$ of respondents use them; $29 \%$ of respondents use Russian library systems. More than $60 \%$ of respondents prefer open Internet resources. Only $1 \%$ of respondents have said that they used all types of resources. Ignorance of a foreign language and inactive participation in research activities can be cited as the main reasons for the low use of foreign databases.

Respondents were asked to identify the most preferred forms of group work. More than $45 \%$ chose meetings with famous people, $23.8 \%$ chose clubs based on common interests; $26.7 \%$ chose English Speaking Club. Other formats drew less interest from the interviewed. For example, competitions were chosen by $12.3 \%$; discussion events were chosen by $11.3 \%$. Students want to take part in various events held in the library.

Answering the question 'What changes are necessary in the library, in your opinion?', the

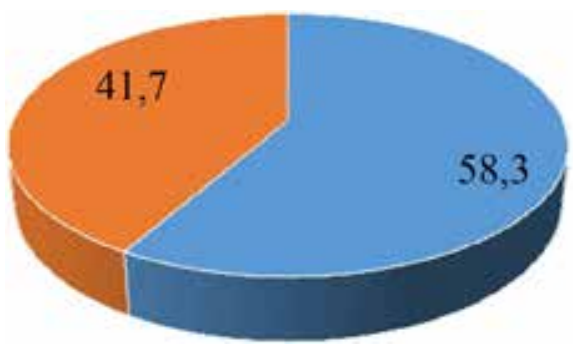

= Electronic
resources
= Printing editions

Fig. 2. Users' preferences

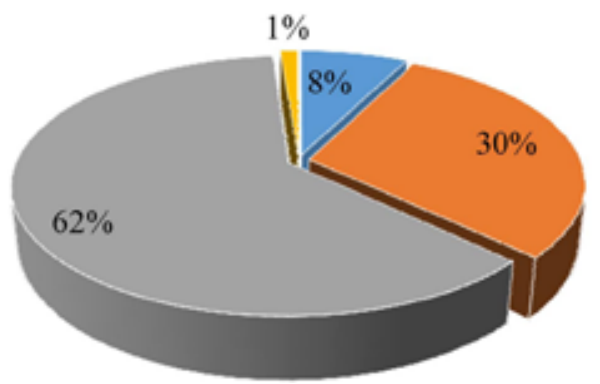
= Foreign DB
= Russian DBs and
Electronic Library
Systems
= Internet
= All resources

Fig. 3. Use of Russian and foreign electronic resources 
majority of readers $(62.3 \%)$ answered that they don't have any problems using library, 22.5\% indicated that they want to receive information about the ends of books' terms of use, new available literature, events held in the library by SMS or e-mail. $30.6 \%$ of respondents have told some ideas for computer and software upgrades; $21.9 \%$ wanted faster Internet connection; $15.4 \%$ wanted rooms for groups of people working together separated from reading rooms; $7.5 \%$ wanted to extend library working hours.

In general, students are satisfied with the conditions of work in the library. The study will make it possible to implement a systematic approach to management to set forward-looking goals, to prioritize current tasks, to develop and implement the necessary organizational and economic activities.

Thus, the main directions for the library's development can be determined based on the review of literature and the research and questionnaire carried out: formation of information resources (printed and digital), development of new services and maintenance of old ones. The library needs to find new ways to interact with its users, modernize the old ones and use new work technologies, preserve the traditions and make innovations. These trends will allow the library to maintain its significance in the era of the Fourth Industrial Revolution.

\section{Results and analysis}

\subsection{Analysis of information resources of the Siberian Federal University}

\section{Scientific Library}

The SFU Scientific Library is being actively modified. The Library is mastering a new paradigm of information requests and information needs of users. Information is becoming an important factor influencing the university's educational and research activities. The foundation core of the SFU Library consists of printed publications and electronic resources on the main educational programs and scientific directions of the university.

Currently, the fund of the SFU Scientific Library on material mediums amounts to about two million copies of documents (see Table 1).
The number of electronic resources is more than 66 million. The library prioritizes to electronic resources in the collection of the fund.

Table 1 shows that every year the number of literature received on material mediums decreases. The number of resources in digital format is increasing.

For three years the SFU Library has been creating its own Archive of electronic resources. The archive contains about 100 thousand titles of full-texts of dissertations, final qualification works, materials of conferences, seminars and other publications of university employees.

To meet the needs of users, such Russian databases as the scientific electronic library eLIBRARY, EastView, management electronic library, marketing and finance Grebennikon. The library began to acquire more international research works. Access is granted to licensed full-text international databases such as Computers \& Applied Sciences Complete, INSPEC, ORBIT Intelligence, ProQuest Dissections \& Things Global, Taylor \& Francis, Wiley are actively used.

Totally, there are 52 full-text electronic databases of textbooks, monographs, articles, periodicals, patents, full-texts of theses, final qualification works, video sessions, etc. available through the subscription of the SFU Scientific Library.

Thus, the development direction of the SFU Scientific Library fund shifts towards electronic information resources. Electronic publications have advantages: they contain diverse, up-to-date scientific information, are available to users from anywhere in the world with access to the Internet.

\subsection{User activity in the SFU Scientific Library}

The number of readers of the university library depends on the number of students. The Scientific Library does intensive work with freshmen $-92 \%$ of first-year students enroll in the library. The total number of library users on the unified reading ticket is 28292 people, $93 \%$ of them are students (see Fig. 4).

Free access to information is provided by a network of 13 subscription departments and 17 reading rooms. Information and bibliographic services for readers are carried out 
Table 1. Quantitative composition of the SFU fund, copies

\begin{tabular}{|l|c|c|c|}
\hline \multicolumn{1}{|c|}{ Indicator/Year } & 2017 & 2018 & 2019 \\
\hline Fund of printed publications & 2052002 & 1967543 & 1831732 \\
\hline Fund of electronic publications & 66000000 & 66073707 & 66154808 \\
\hline Receiving of printed publications: & 8816 & 8069 & 6464 \\
\hline SFU publications & 1232 & 922 & 1374 \\
\hline Periodicals & 291 & 287 & 231 \\
\hline Receiving of electronic publications: & 73555 & 73707 & 407 \\
\hline SFU publications & 412 & 463 & 376 \\
\hline Periodicals & 235 & 297 & 81 \\
\hline
\end{tabular}

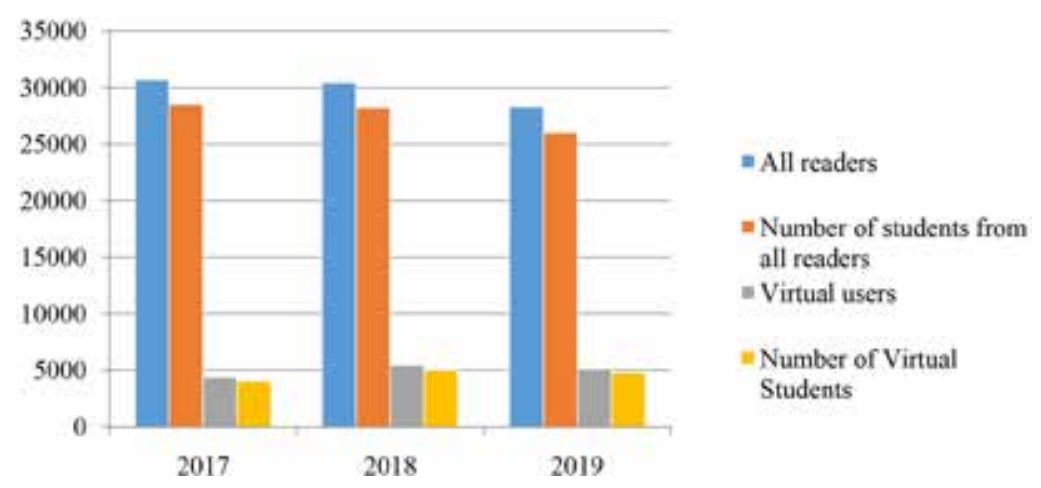

Fig. 4. SFU library readers and virtual users

in an automated mode: accounting and registration of users; booking, reception, issuance and re-registration of literature.

The number of visits is the main criterion for the attractiveness of the library. By 2019, the number of remote visits exceeded the number of physical visits. According to the results of the questionnaire, users prefer printed and electronic resources almost equally. Electronic resources, according to statistics, are in demand by a quarter more than printed publications (see Fig. 5).

This situation has established due to the fact that, firstly, the SFU buildings are located in different parts of the city. It is easier for users to receive services remotely. Secondly, a large number of electronic databases of educational and scientific information are available through the library's subscription. Thirdly, the Scientific Library has developed a convenient technology to serve remote users. This increases the demand for online services.
The Scientific Library provides a wide range of services: inter-library subscription, printing on demand, extension of literature's loan period, booking of publications, introduction of a publication to the Russian Index of Scientific Citation, registration of the literature list, verification of the impact factor of the magazine, etc. The use of information technologies in the library allows to automate the system of service to readers as much as possible. Users can receive these services online. The Scientific Library website provides access to electronic resources and services.

Library services satisfy most utilitarian and intellectual requirements of teachers and students. Development and implementation of new services ensure effective access of users to full-text domestic and foreign resources. Copyright and intellectual property protection laws are respected. Automated services effectively redistribute the workload of library employees. 

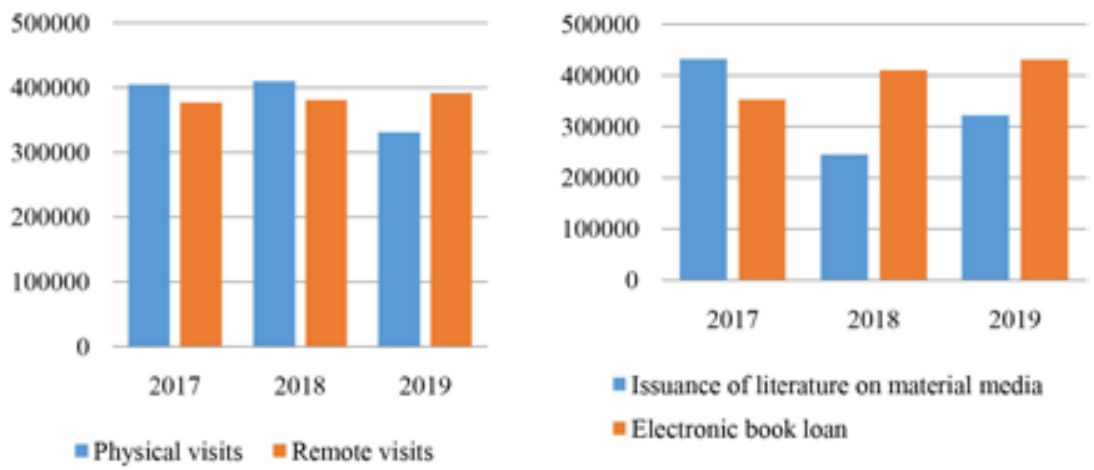

Fig. 5. Visits and book loan of the SFU Library

Released working time is spent to increase professional competences.

Training of all categories of users is carried out to create an information culture in different forms:

- Days of the department, days of the diploma, days of information;

- Training on working with information resources;

- Seminars and master classes;

- Courses on the choice of "Basics of information culture"; "Information resources for education";

- Electronic course "Digital information resources for research and educational activities" in the e-Siberia system of the Regional Competence Center in the field of online training in Krasnoyarsk.

The SFU Scientific Library solves the task of forming information competences of users, implements models of learning through life, learning through practice and develops in accordance with modern trends in educational activities.

Thus, the wide distribution of electronic information resources in the world leads to changes in the activities of library and information institutions. The library's role changes in an electronic environment.

\subsection{Cultural and leisure activities of the SFU Scientific Library}

Library services for users can change due to various factors. These factors include the transformation of political, social and economic conditions in the country, the information interests and needs of society and individual users. Libraries take an active part in cultural activities, become cultural and leisure centers of universities.

It can be noted that in the digital environment, the lack of living human communication is more clear. Libraries position themselves as a space for intellectual leisure.

The modern stage of cultural and mass activity development of libraries is characterized by a large space for creativity. Librarians use multimedia technologies, web design, Internet in their work. Mass work develops in a new way. Innovative approaches are combined with traditional methods. Multimedia resources make events more bright and colorful. The display of videos, slides, photos, illustrations, electronic publications on the big screen make introduction to the book more effective.

The SFU Scientific Library actively participates in the life of the university, coordinates its activities with the Department of Educational Work, the Center of Student Culture. Such major events as thematic evenings, meetings with writers, reading conferences, photo exhibitions, competitions, science festivals, debates, oral magazines, book exhibitions, lectures, musical changes, excursions are held in the library. At the same time, new forms of mass events appear: Bibliography, Bibliofest, Piano Bridges, Open rostrum of readers, etc.

The library staff organized about 500 book exhibitions during the year, held more than 150 educational events. For example, event "Create a masterpiece" (colouring sketches of paintings of great artists) has become popular among 
readers. "Book Swap" has started, participants exchange books, share the history of books acquisition. Projects "Art Window", "Literature Teahouse". "Restaurant stories" are in popular among students. The campaign to collect books "Present books with love" was carried out in collaboration with the SFU volunteer center. Projects to create a photo zones in the library contribute to the attractiveness of books and libraries. They focus on visualization of book and reading, information technology, scientific and educational information, etc.

Library quests are very popular among students: "Fasting Cuisine" about the healthy nutrition of students; "On the Steps to Knowledge" promotes library's resources and services in a form of a game; "Library Lesson" for junior school students. The contest of readers "About love, about spring" collects more than 40 participants annually. It aims to encourage youth for creative activity and identify talented ones among them.

Promoting the library on social media is a fairly new activity for libraries. Social networks are popular and an effective way to promote libraries. Libraries create groups and pages to contact readers and draw their attention to library activities.

The SFU Scientific Library has representation in popular social networks: VKontakte, Facebook, Twitter, Instagram. Library staff maintain their YouTube channel. A study conducted in the SFU Library showed that the most readers consist in the Vkontakte group of library - more than two thousand users.

Actions and competitions are held to attract new participants. They are timed to the holidays. A creative competition called "55 words" about students' life and library is held annually in October. Library events, reports, polls are featured on Instagram. More than a hundred stories are shot with photos and videos of reading rooms.

Thus, social networks allow to quickly inform the target audience about approaching events, current actions, changes in the schedule of work. Positioning allows libraries to develop in social media in line with the university 's in- formation policy. Information services become more accessible to users.

The SFU Scientific Library provides comprehensive information support to the university in the provision of quality educational services and organization of scientific research and leisure activities. Modern information and education technologies facilitate the fastest, most comfortable and efficient access for users to information according to their needs and goals. Resource promotion is implemented actively. User training is conducted regularly in a virtual environment. The success and effectiveness of the chosen model of library activity is confirmed by recognition in Russia. The projects "SFU Electronic Library" and "Publication Activity Support Service in the SFU Library" became winners in the All-Russian Competition of Library Innovations.

\section{Conclusion}

The University Library was and still is the main information center in system of higher professional education. The potential of the modern library is estimated not only by the volume and completeness of the book fund, but also by its relevance and the ability of the library to provide the latest information as soon as possible to all its users.

Modern libraries are in a period of adaptation to the new realities of the digital era, they have to start reforming their own activities, based on the specific needs of the served audience (Stepanov, 2018).

The University Library provides comprehensive information support for the University's activities in providing quality educational services, organizing scientific research and developing partnerships with other organizations. Using modern information and education technologies, library facilitates the fastest, most comfortable and efficient access of users to information according to their needs and goals. It is acceptable to say that libraries got their own "branch" on the Internet. It is exactly the same library, with the same features of resource generation and promotion, service and user training, but in a virtual environment. 


\section{References}

Aleksankov, A.M. (2017). Chetvertaja promyshlennaja revoljucija i modernizacija obrazovanija: mezhdunarodnyj opyt [The Fourth Industrial Revolution and Modernization of Education: International Experience]. In Kul'tura i bezopasnost': Internet-zhurnal o kul'ture kak faktore nacional'noj bezopasnosti [Culture and Security: Internet Magazine on Culture as a Factor of National Security], available at: http:// sec.chgik.ru/chetvertaya-promyishlennaya-revolyutsiya-i-modernizatsiya-obrazovaniya-mezhdunarodnyiy-opyit-2/.

Alzahrani, A.I., Imran, M., Ramayah, T., Alfarraj, O., Alalwan, N. (2019). Modelling digital library success using the DeLone and McLean information system success model. In Journal of Librarianship and Information Science, 51(2), 291-306.

Babich, I.V. (2017). U istokov bor'by za vyzhivanie: Sociokul'turnaja dejatel'nost' rossijskih bibliotek na rubezhe HH-XXI vekov [At the Origin of the Struggle for Survival: Social and cultural Activity of Russian Libraries at the Turn of the XX-XXI Centuries]. In Bibliotechnoe delo [Library Science], 21, 39-43.

Basov, S.A. (2008). Grazhdanskaja missija publichnoj biblioteki [Civic Mission of the Public Library], Informacionnyj bjulleten' Rossijskoj bibliotechnoj associacii [In Newsletter of the Russian Library Association], 7, 30-33.

Chernyj, Yu.Yu. (2018). Mediasreda prishla v dvizhenie: perspektivy mediaobrazovanija v uslovijah cifrovoj jekonomiki [Media has come into motion: prospects for media education in the digital economy]. In Media. Informacija. Kommunikacija [Media. Information. Communication], 27, 1-7, available at: http:// mic.org.ru/phocadownload/27-cherny.pdf

Chunmeng, W., Jinzhu, C., Feiyun, Z. (2019). Research on Technology Empowerment in Digital Transformation of Library in Information Age. In International Conference on Computer, Information and Telecommunication Systems (CITS), 1-10. DOI:10.1109/CITS.2019.8862115

Decree of the President of the Russian Federation of 09.05.2017 No. 203 "About the Development strategy of information society in the Russian Federation for 2017 - 2030" (2017), available at: http://www. kremlin.ru/acts/bank/41919

Diaz, M.V., Matheus-Chacin, C.A., García-Crespo, A., García-Encabo, I. (2019). Comprende: A Digital Media Library for All. In 14th Iberian Conference on Information Systems and Technologies (CISTI), 1-5.

Federal Law “On Library Case” of May 1, 2019 No. 78-FL (last edition) (2019), available at: http://docs. cntd.ru/document/9010022

Federal Project "Regulatory Regulation of the Digital Environment" (2018), available at: https://digital. gov.ru/uploaded/files/pasport-federalnogo-proekta-normativnoe-regulirovanie-tsifrovoj-sredyi.pdf

Gendina, N.I., Ryabtseva, L.N. (2018). Izmenenie funkcij bibliotek v jepohu sociokul'turnyh transformacij: social'nye riski i problema vybora orientirov [Changing the Functions of Libraries in the Era of Sociocultural Transformation: Social Risks and the Problem of Choice of Reference Points]. In Bibliotekovedenie [Library Science], 67 (3), 257-265, available at: https://doi.org/10.25281/0869-608X-2018-67-3-257-265

Gendina, N.I., Ryabtseva, L.N. (2018). Biblioteki v jepohu sociokul'turnyh transformacij: sovremennye vyzovy i osnovanija dokazatel'nogo bibliotekovedenija [Libraries during an era of sociocultural transformations: modern calls and bases of evidential library science]. In Bibliotekovedenie [Library science], 67 (1), 7-15, available at: https://doi.org/10.25281/0869-608X-2018-67-1-7-15

Gurdish, S. (2018). The Role of Academic Libraries in the Digital Transformation of the Universities. In 5th International Symposium on Emerging Trends and Technologies in Libraries and Information Services, 293-296.

Kondakov, A.M. (2017). Obrazovanie v jepohu chetvertoj promyshlennoj revoljucii [Education in the Era of the Fourth Industrial Revolution]. In Vesti obrazovanija [News of Education], available at: https://vogazeta.ru/articles/2017/9/20/analitycs/252-obrazovanie_v_epohu_chetvertoy_promyshlennoy_revolyutsii

Kovaleva, M. (2013). Chtoby privlech' ljudej v biblioteki, im nuzhno predlozhit' gorazdo bol'she, chem tol'ko knigi [To attract people to libraries, they need to offer much more than only books]. In Bibliotechnoe delo [Library Science], 1, 25-26. 
Kudryashova, G.Y. (2004). Jevoljucija missii bibliotek otechestvennyh vysshih uchebnyh zavedenij [Evolution of the Mission of Libraries of Domestic Higher Education Institutions]. Yekaterinburg, 133 p.

Kuznetsova, T.J. (2019). Funkcional'naja model' biblioteki cifrovoj jepohi [Functional Model of the Library of the Digital Age]". In Bibliografija [Bibliography], 5, 3-13.

Lenka, S. Parida, V. Wincen, T. (2017). Digitalization Capabilities as Enablers of Value Co Creation in Sovietizing Firms. In Psychology and Marketing, 34(1), 92-100.

Limwichitr, S. (2019). From Knowledge to Innovation: Transformation of Thai Academic Libraries in Times of Digital Disruption. In DSDE, 1-12. https://doi.org/10.1145/3354153.3354159

Lippincott, J.K. (2015). Libraries and the digital university. In Coll. Res. Libr., 76, 3, 283-295.

Mazuritsky, A.M., Kuzichkin, G.A. (2019). Modern Library and Time Challenges. In Scientific and Technical Libraries, 5, 22-36.

Message of the President of the Russian Federation to Federal Assembly of 01.12.2016 (2016), available at: http://www.consultant.ru/document/cons_doc_LAW_207978/

Order dated July 28, 2017 No. 1632-r Program "Digital Economy of the Russian Federation" (2017), available at: http://static.goverment.ru/media/files/9gFM4FHj4PsB79I5v7yLVuPgu4bvR7M0.pdf

Order of the Government of the Russian Federation No. 2400-r of November 3, 2018 On the Establishment of an Autonomous Non-Profit Organization Platform of the National Technological Initiative (2018), available at: https://www.garant.ru/products/ipo/prime/doc/71997678

Otstavnova, I.V., Shamatonova, G.L. (2018). Komplektovanie fondov vuzovskoj biblioteki: problemy i puti reshenija [Collection of Funds of the University Library: Problems and Ways of Solving]. In Nauchnye i tehnicheskie biblioteki [Scientific and Technical Libraries], 5, 81-91.

Passport of the federal project "Digital State Administration" (2018). available at: https://digital.gov. $\mathrm{ru} /$ uploaded/files/pasport-federalnogo-proekta-tsifrovoe-gosudarstvennoe-upravlenie.pdf

Passport of the federal project "Digital Technologies" (2018), available at: https://www.tadviser.ru/images/0/0f/\%D0\%A3\%D1\%82\%D0\%B2_\%D0\%A4\%D0\%9F_5_\%D0\%A4\%D0\%9F_\%D0\%A6\%D0\%A2.pdf

Passport of the federal project "Personnel for Digital Economy" (2018). Available at: https://digital. gov.ru/uploaded/files/pasport-federalnogo-proekta-kadryi-dlya-tsifrovoj-ekonomiki.pdf

Passport of the national program "Digital Economy of the Russian Federation" (Approved by presidium of Council at the President of the Russian Federation for strategic development and national projects on December 24, 2018 No 16) (2018). Available at: https://base.garant.ru/72190282/

Passport of the national project "Culture" (Approved by presidium of Council at the President of the Russian Federation for strategic development and national projects (the protocol of December 24, 2018 No 16)) (2018).A at: http://government.ru/info/35562/

Passport of the national project "Education" (Approved by presidium of Council at the President of the Russian Federation for strategic development and national projects (the protocol of December 24, 2018 No 16)) (2018). Available at: https://base.garant.ru/72192486/

Passport of the national project "Science" (Approved by presidium of Council at the President of the Russian Federation for strategic development and national projects (the protocol of December 24, 2018 No 16)) (2018). Available at: http://government.ru/projects/selection/740/35565/

Rassadina, M.I. (2018). Biblioteka v uslovijah global'noj informatizacii: problemy transformacii [Library in the Conditions of Global Informatization: Transformation Problems], Nauchnye i tehnicheskie biblioteki [Scientific and Technical Libraries], 1, 51-60.

Raza, M., (2019). Application of linked data technologies in digital libraries: a review of literature. In Library Hi Tech News, 36 (3), 9-12, available at: https://doi.org/10.1108/LHTN-10-2018-0067

Resolution of the Government of the Russian Federation of April 18, 2016 No 317 "About realization of the National technological initiative" (2016), available at: https://base.garant.ru/71380666/

Rosa, I. (2019). Digital Library Polona: Digitization, Technology, Cooperation, Slavic \& East European Information. In Resources, 20:1-2, 23-30, DOI:10.1080/15228886.2019.1628495

Schreiberg, Y.L (2019). Informacionno-dokumentnoe prostranstvo obrazovanija, nauki i kul'tury v sovremennyh uslovijah cifrovizacii obshhestva [Information and Documentary Space of Education, Sci- 
ence and Culture in Modern Conditions of Digitalization of Society]. In Scientific and Technical Libraries, 9. 3-55.

Schreiberg, Y.L. (2018). [Formation of a Single Knowledge Space on the Basis of Network Information Infrastructure in Conditions of Formation and Development of Modern Digital Economy]. In Nauchnye $i$ tehnicheskie biblioteki [Scientific and Technical Libraries], 9, 3-76.

Schreiberg, Y.L. (2018). Budushhee zavisit ot nas [The Future Depends on Us]. In Nauchnye i tehnicheskie biblioteki [Scientific and Technical Libraries], 12, 5-10.

Shen, Y. (2019), Emerging scenarios of data infrastructure and novel concepts of digital libraries in intelligent infrastructure for human-centered communities: A qualitative research. In Journal of information science, 45 (5), 691-704.

Schwab, K. (2016). “Fourth Industrial Revolution”. In Exmo Publ., Moscow, 208 p.

Shamatonova, G.L. (2017). "Library of the University in a Changing Educational Space". In Scientific and Technical Libraries, 2, 51-56.

Sokolov, A.V. (2009). "Missions and Mutations of Libraries". In Library Affairs, 14, 2-10.

Sokolskaya, L.V., Russak, Z.V. (2015). "Modern Library: Loss of Identity or Acquisition of New Social Meanings?" In Journal of the Chelyabinsk State Academy of Culture and Arts, 1 (41), available at: https://cyberleninka.ru/article/v/sovremennaya-biblioteka-utrata-identichnosti-ili-priobretenie-novyh-sotsialnyh-smyslov

Stepanov, V.K. (2017). Bol'she, chem knigi: biblioteka i bibliotekari v mire, gde menjaetsja vsjo [More than books: library and librarians in a world where everything changes]. In Nauchnye i tehnicheskie biblioteki [Scientific and technical libraries], 1, 19-25.

Stepanov, V.K. (2018). Biblioteka i bibliotekari v blizhajshie dvadcat' let, ili v ozhidanii singuljarnosti [Library and librarians in the next twenty years, or in anticipation of singularity]. In Nauchnye i tehnicheskie biblioteki [Scientific and technical libraries], 1, 19-31.

Tikhomirova, I.I. (2012). Biblioteka: krizis identichnosti. Est' li vyhod? [Library: Identity Crisis. Is there a way out?]. In Bibliotechnoe delo [Library Science], 20, 7-11.

Vahrushev, M.V. (2018). Nauchnaja biblioteka vuza v roli otkrytogo arhiva [Scientific Library of the University in the Role of Open Archive]. In Nauchnye i tehnicheskie biblioteki [Scientific and Technical Libraries], 4, 14-22.

Verbatim report of the plenary session of the St. Petersburg International Economic Forum (2018). Available at: http://www.kremlin.ru/events/president/news/54667

Vtyurina, V. (2019). Jelektronnye biblioteki kak resursnaja baza dlja obespechenija uchebnoj i nauchnoj dejatel'nosti universiteta [Electronic Libraries as a Resource Base for the University 's Educational and Scientific Activities]. In Nauchnye i tehnicheskie biblioteki [Scientific and Technical Libraries], 6, 87-94.

\title{
Трансформация университетских библиотек в цифровую эпоху
}

\author{
Р.А. Барышев, И.А. Цветочкина, О.И. Бабина, \\ Е.Н. Касянчук, М.М. Манушкина \\ Сибирский федеральный университет \\ Российская Федерачия, Красноярск
}

\begin{abstract}
Аннотация. В статье рассматривается переходный период развития общества, основанный на использовании цифровых информационно-коммуникационных технологий. В настоящее время цифровая экономика охватывает все сферы
\end{abstract}


жизни общества, поэтому вопрос ее изучения является актуальным. Переход к новой модели цифровой экономики способствует повышению качества жизни населения. В высших учебных заведениях изменяются образовательные траектории, наблюдается стремительный переход от физической к виртуальной реальности. Однако образовательная среда существенно отстает от темпов развития промышленного производства на базе современных технологий. В такой ситуации необходимо вырабатывать подходы к модернизации системы подготовки кадров. В связи с этим разрабатываются стратегии университетов, нацеленные на создание полноценных условий для развития образования и науки, получение информации и знаний, поступающих из интеллектуальной глобальной среды. В условиях перехода к цифровым технологиям в образовании библиотека, как одно из основных структурных подразделений вуза, должна тоже стать цифровой.

Раскрыты различные точки зрения библиотечного сообщества, которые показывают стратегию и направление развития библиотеки для цифровой среды. В настоящее время библиотеки активно развивают информационно-коммуникационные технологии в предоставлении услуг своим пользователям, при этом сохраняя традиционные формы и методы работы с читателями. Такой симбиоз позволяет удовлетворять потребности различных групп читателей и пользователей.

На основе теоретического исследования процессов формирования и развития электронной библиотеки рассмотрены проблемы переходного периода, обозначена стратегия развития цифровой библиотеки, определены технологии создания и внедрения информационных ресурсов в образовательную среду университета.

Данное исследование было проведено с целью изучения активности использования информационных ресурсов в учебном процессе и научно-исследовательской деятельности, для повышения качества обслуживания пользователей библиотеки. Оно позволит выявить отношение студентов к информационным ресурсам и библиотечным сервисам.

Отмечается актуальность и значимость перехода к цифровой библиотеке, влияние этого процесса на развитие всех видов деятельности при сохранении неизменности ее основного функционального назначения. Кроме того, указывается появление новых социальных и технологических задач, подчеркивается специфика работы с цифровыми пользователями. Работа библиотеки рассматривается как с виртуальными пользователями, так и реальными читателями. Анализируется книговыдача и предоставление электронных ресурсов пользователям. Деятельность библиотеки состоит в проведении просветительских и досуговых мероприятий со студентами и преподавателями университета.

Представленные рекомендации позволят повысить эффективность деятельности библиотеки.

Ключевые слова: четвертая промышленная революция, цифровизация, цифровая экономика, виртуальная среда, библиотеки, информационные ресурсы, библиотечные сервисы.

Научные специальности: 07.00.00 - исторические науки, 24.00.00 - культурология. 